\title{
The Relationship between Financial Distress and Financial Health Prediction Model: A Study in Public Manufacturing Companies Listed on Indonesia Stock Exchange (IDX)
}

\author{
Khaira Amalia Fachrudin \\ Faculty of Economics and Business, Universitas Sumatera Utara \\ Jl. TM Hanafiah USU Campus, Medan 20155, Indonesia \\ Email: khaira@usu.ac.id
}

\begin{abstract}
Financial distress prediction models of Altman, Springate, Zmijewski, Grover, and Khaira have been widely applied to predict financial distress and financial health. This study aims to analyze score correlations within the prediction results of the mentioned models applied in manufacture companies listed in the Indonesian Stock Exchange. The sample includes 30 companies which faced financial distress during economic crisis in 1997-1998 and, as comparison, incorporates 28 financially healthy companies. Observations were made during one and two years before the financial distress occurred, i.e. between 1995 until 1999, as well as from 2015 until 2018 to measure the financial health level in the companies. In this study, we use the correlation analysis. The results showed that models which have a strong and significant relationship at alpha 5\% are models from Altman - Springate, Altman - Khaira, Springate - Khaira, and Zmijewski - Khaira. Grover model which does not have the predictor in the form of leverage, however has a weak correlation with other model as well as the actual condition.
\end{abstract}

Keywords: Financial distress; financial health; profitability; leverage.

\section{INTRODUCTION}

Financial distress is a condition of a company whose cash flow is not sufficient to pay its financial obligation. This situation may cause the company fails to fulfill the contract and require debt restructuring. Insolvency is the inability of a person to pay the debt [22]. The Financial distress is also known as bankruptcy failure, corporate failure, financial risk, financial insolvency, and/or credit default [13]. Financial distress reflects various levels of corporate adversity. The researchers see the financial distress in the context of insolvency, failure or corporate restructuring [3], whereas the insolvency in bankruptcy is a state of the company whose book value of debt is greater than the market value of its asset [9].

Financial distress can be caused by business failure, disaster and accident, fraud and cheating, economic condition, inadequate corporate funding, lack of experience, improper business strategy, operational problem, and lack of competence [9]. While the prediction of financial distress is very important for companies to take preventative measures, this is also important factor for investors and potential investors in making the investment decision.

Bankruptcy prediction model and financial distress prediction have been carried out by Altman [2], Springate [25], Zmijewski [27], Grover [11] and
Fachrudin [9]. Fachrudin model is also called Khaira model. These five prediction models provide guidance on what score the company is categorized as the company experiencing financial distress and on what score it is categorized as a healthy company, however the Ohlson, Doumpus and Zopounidis prediction models [9] [5] do not provide score information to indicate financial distress of the company. Altman, Springate, Zmijewski, Grover and Khaira prediction models were made at different places, times, types of companies and the definitions of financial distress, whereas the results of these predictions are also used to predict financial distress under different conditions. For example, the Altman, Springate, and Zmijewski are used to predict potential bankruptcy in telecommunication vendor company [20]; Altman's Z score is used in research about the correlation between corporate social responsibility expenditure, financial distress prediction, and the reputation of Indonesia's manufacturing companies [1]; Altman's prediction model is used to observe financial performance of organization before making investment decisions [19]; The Altman Z-Score is used in estimating the effect of corporate governance practices on financial distress [23]; Fulmer and Springate prediction models for predicting solvency of non-bank financial institutions in India [13]; prediction of financial distress of coal companies in Indonesia with the Springate, 
Grover, and Zmijewski models [12], as well as the Khaira model used in research on the effect of financial distress and firm size on the value of property and real estate companies in Indonesia, whereas the accuracy and structure of the model can change over time, especially if the population used is different [10].

Financial distress prediction using predictors in the form of financial ratios [15], including the profitability ratio, capital structure, liquidity, and asset management. Nonetheless a good ratio to distinguish between companies that fail and those that do not fail is the ratio of return on assets, return on capital, and earnings per share. All three are profitability ratios [5].

The financial distress prediction model can also be used to predict the financial health of a company [4]. Its application has been carried out in research to determine the soundness of manufacturing companies in Indonesia using the Altman, Springate, and Zmijewski models [24], research in India aimed to measures the financial health of companies using the Altman model [17], and research on the banking industry in Bangladesh which predict financial health using the Altman model [21].

These five prediction models give a cut off on what value the company is categorized to have financial distress, at what value it does not, and at what value is in the grey area, for example Altman gives a cut-off where the score less than 1.23 would be potentially bankrupt, however according Springer the score which smaller than 0.862 would be potentially bankrupt. When compared to these scores directly, it is not comparable or not apple to apple. Therefore the scores need to be balanced in the range of 0 to 1 , where 0 is a company that is not experiencing financial distress and 1 is a company that is experiencing financial distress.

In Indonesia, due to the 1997- 1998 financial crisis, 30 manufacturing companies listed on the Indonesia Stock Exchange experienced financial distress with insolvency types. Most cases of financial distress are caused by the use of debt - especially in foreign currencies - which is enormous. When the rupiah exchange rate weakens, the amount of debt of these companies swells. The prediction model of financial distress has been studied and it is true that the predictors are the debt ratio and profitability ratio [9]. Profitability decreases with one of the causes being losses due to foreign exchange differences.

This research wants to compare and analyze the correlation between the financial distress prediction models and the level of company financial health by connecting the scores generated from the Altman, Springate, Zmijewski, Grover, and Khaira models, in order to support decision-making. Thus, if the predictive score of a model correlates with other model, then these models can be used together to support the financial distress prediction.

\section{Theory of Financial Distress}

The theory of financial distress is presented graphically as a condition that is influenced by the balance sheet influence and earnings effect [19]. Balance sheet influence includes liquidity (working capital to total assets), activity (sales to working capital), and financial leverage (market value of equity to book value of debt) ratio. While the earning effect includes profitability (earnings before interest and tax to working capital), and retained earnings to working capital ratio. For conditions in Indonesia, financial distress are more influenced by financial leverage and profitability.

The types of theoretical models that determine the causes of bankruptcy are balance sheet decomposition measures, gambler's ruin theory, cash management theory, and credit risk theories. Balance sheet decomposition measures identify financial distress by examining changes in the structure of the balance sheet, with the argument that companies try to maintain the equilibrium of their financial structures. Gambler's ruin theory considers that the company as a gambling player has a chance of loss repeatedly and continues operations until his net assets become zero (bankrupt). Cash management theory pays attention to shortterm cash balances. An imbalance between cash inflows and cash outflows will mean a failure of the company's cash management function. If this happens on an ongoing basis it will cause financial distress and will go bankrupt. Credit risk theories use a credit approach and risk measurement. The credit cycle follows the business cycle, with probability of failure to be a function of variables such as unemployment rates, interest rates, growth rates, government spending, foreign exchange rates, and aggregate savings. A worsening economy will be followed by the failure of securities downgrade [9].

\section{Financial Distress Prediction Model}

Altman [2] conducted a multiple discriminant analysis test on 53 manufacturing and retail companies that were included in the list of bankruptcy requests (distressed) and 58 companies that were not bankrupt (non-distressed) to obtain a bankruptcy prediction model. Non-bankrupt groups are adjusted according to the type of industry and year by the bankrupt company. The model obtained is a revision of the model he had previously made so called the Revised Z-Score, namely: 


$$
\begin{aligned}
Z^{\prime \prime}= & 0.717\left(\mathrm{X}_{1}\right)+0.847\left(\mathrm{X}_{2}\right)+3.107\left(\mathrm{X}_{3}\right)+0.420\left(\mathrm{X}_{4}\right) \\
& +0.998\left(\mathrm{X}_{5}\right)
\end{aligned}
$$

Where:

$\mathrm{X}_{1}=$ working capital $/$ total assets

$\mathrm{X}_{2}=$ retained earnings/total assets

$\mathrm{X}_{3}=$ earnings before interest and taxes/total assets

$\mathrm{X}_{4}=$ book value equity/book value of total liabilities

$\mathrm{X}_{5}=$ sales/total assets

If the score $<1.23$, the company has the potential to go bankrupt. Scores 1.23 to 2.9 are classified as grey areas, while scores $>2.9$ are classified as not having the potential to go bankrupt. This Altman model has a classification accuracy of $90 \%$.

Springate follows the procedure developed by Altman using multiple discriminant analysis - step wise by using 19 popular financial ratios to distinguish between healthy and bankrupt companies [25], [4]. Springate uses 40 large companies in Canada [14] and obtains an accuracy rate of $92.5 \%$. The Springate model is as follows:

S-Score $=1.03 \mathrm{X}_{1}+3.07 \mathrm{X}_{2}+0.66 \mathrm{X}_{3}+0.4 \mathrm{X}_{4}$

Where:

$\mathrm{X}_{1}=$ working capital/total assets

$\mathrm{X}_{2}=$ earning before interest and taxes $(E B I T) /$ total assets

$\mathrm{X}_{3}=$ net income before taxes $(E B I T) /$ current liabilities

$\mathrm{X}_{4}=$ sales/total assets

If the Springate Z-score is smaller than 0.862 then the company is predicted to go bankrupt, however if the score is greater than 0.862, the company will be predicted to be healthy [14].

Zmijewski used a sample of 400 bankrupt companies and 800 non-bankrupt companies listed on the American and New York Stock Exchange during 1972-1978 [27]. The bankrupt company in this case refers to a company listed in the bankruptcy request list. This prediction model is not carried out for specific industries and can be applied universally across industries. By using probit analysis, the following model is generated:

$b^{*}=-4.3-4.5 \mathrm{X}_{1}+5.7 \mathrm{X}_{2}-0.004 \mathrm{X}_{3}$

Where:

$\mathrm{X}_{1}=$ net income $/$ total assets

$\mathrm{X}_{2}=$ total debt $/$ total assets

$\mathrm{X}_{3}=$ current assets $/$ current liabilities

If $b * 0$, then the company is predicted to potentially experience bankruptcy, whereas if $\mathrm{b} *<0$ then the company is predicted to have no potential to go bankrupt. This model has an accuracy of $99 \%$.

Grover continued the study of Altman by using 254 bankrupt companies [11]. The model is as follows:
$\mathrm{Z}=1.650 \mathrm{X}_{1}+3.404 \mathrm{X}_{2}-0.016 \mathrm{X}_{3}+0,057$

Where:

$\mathrm{X}_{1}=$ working capital $/$ total assets

$\mathrm{X}_{2}=$ earning before interest and taxes/total assets

$\mathrm{X}_{3}=$ net income $/$ total assets

If $Z<=-0.02$ then the company is categorized as bankrupt and if $\mathrm{Z}>=0.01$ then the company is categorized as not bankrupt.

Fachrudin conducted research on 30 manufacturing companies that experienced financial distress with insolvency type due to the economic crisis of 1997 and 1998 and used 28 healthy manufacturing companies as comparisons [9]. The criteria for financial distress used are net income that has been negative for three years or more; experiencing debt default (default) that leads to debt restructuring; and has a smaller amount of assets than total liabilities for 3 years or more. Three of the 30 company shares that experienced financial distress in 2003 and 2004 experienced delisting, and three more were suspended. As a comparisons, this study used companies with no financial distress who have the following criteria: never get a negative net profit or at least 1 time in the period 1995-2005; not experiencing default and not restructuring debt; and the amount of assets is always greater than the amount of the liability. The prediction used logistic regression test with stepwise procedures for one year and two years before financial distress occur. This model is called the Khaira model with the following formula:

$\mathrm{P}_{\mathrm{i}}=1 /\left[1+\exp \left(-5.472+9.555 \mathrm{X}_{1}-32.347 \mathrm{X}_{2}\right)\right]$

This model can be written as:

$\mathrm{P}_{\mathrm{i}}=1 /\left[1+2.718^{-(-5.472+9.555 \mathrm{X} 1-32.347 \mathrm{X} 2)}\right.$

Where:

$\mathrm{Pi}=$ Probability of financial distress, the resulting score ranges between 0 and 1 . Score 0 indicates a healthy company, score 1 indicates a company that is experiencing financial distress. Scores between 0 and 1 indicate the degree of probability of financial distress or the level of health of the company.

$\mathrm{X} 1=$ total liabilities/total assets

$\mathrm{X} 2=$ net income/total assets

This model has $93.1 \%$ prediction accuracy.

\section{Hypothesis Development}

The five prediction models are used equally to predict financial distress and equally have a score limit, at what number is said to be experiencing financial distress and at what number is said to be healthy. If it is applied to predict the same company, which is a manufacturing company in Indonesia, 
there will likely be a correlation between the five models, especially if the score limit is translated in the range of 0 to 1 .

The hypothesis proposed is:

1. There is a positive and significant correlation between the scores of financial distress prediction models of Altman, Springate, Zmijewski, Grover, and Khaira at one year before the financial distress occur.

2. There is a positive and significant correlation between the scores of financial distress prediction models of Altman, Springate, Zmijewski, Grover, and Khaira with the company's actual conditions at one year before the financial distress occur.

3. There is a positive and significant correlation between the scores of financial distress prediction models of the Altman, Springate, Zmijewski, Grover, and Khaira one year before the financial distress occur with the company's actual condition

4. There is a positive and significant correlation between the scores of the Altman, Springate, Zmijewski, Grover, and Khaira in the two years prior to the financial distress with the company's actual condition

5. There is a positive and significant correlation between the scores of the Altman, Springate, Zmijewski, Grover, and Khaira in the years of 2015, 2016, 2017 and 2018.

\section{Research Model}

This research model is presented in Figure 1.
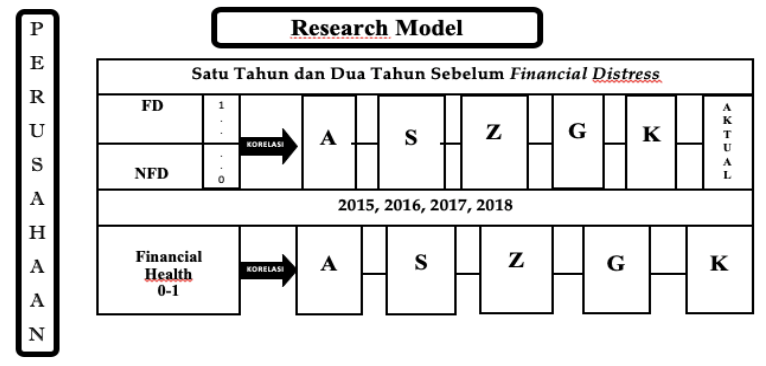

Figure 1. Research Model

Source: [2], [4], [6], [8], [11], [17], [25], [27]

$\mathrm{A}=$ Altman model

$\mathrm{S}=$ Springate model

$\mathrm{Z}=$ Zmijewski model

$\mathrm{G}=$ Grover model

$\mathrm{K}=$ Khaira model

\section{RESEARCH METHOD}

\section{Population Design}

The population used in this study are manufacturing companies listed on the Indonesia Stock Exchange. The target population is a manufacturing company which experienced financial distress with insolvency types that meet the following criteria: generate negative net income for three years or more; experiencing debt default (default) that leads to debt restructuring; and in 3 years or more has a smaller amount of assets than total liabilities. Comparative companies of this case are companies with no financial distress, likewise have the opposite criteria. The period of this FD is different for each company. Thus, the mention of one year and two years prior to financial distress in this study refers to different years. Some began in 1997, 1998, 1999, 2000, and even 2001. Based on these criteria, 30 FD companies and $28 \mathrm{NFD}$ companies were selected.

Financial distress prediction is applied to these 58 companies using the Altman, Springate, Zmijewski, Grover, and Khaira prediction models. The score obtained will indicate whether a company is included in the financial distress group or not. These different scores are then equalized on a scale of 0 to 1 to be compared (Table 1).

Tabel 1. Financial Distress Prediction Score and Equivalent Value

\begin{tabular}{|c|c|c|c|c|}
\hline No. & Model & Score & Prediction & $\begin{array}{l}\text { Equivalent } \\
\text { Value }\end{array}$ \\
\hline \multirow[t]{3}{*}{1} & Altman & $<1.23$ & Financial Distress & 1 \\
\hline & (1977) & $1.23-2.9$ & Grey Area & $0.001-0.999$ \\
\hline & & $>2.9$ & Non Financial Distress & 0 \\
\hline \multirow[t]{2}{*}{2} & Springate & $<0.862$ & Financial Distress & 1 \\
\hline & (1978) & $>0.862$ & Non Financial Distress & 0 \\
\hline \multirow[t]{2}{*}{3} & Zmijewski & $>0$ & Financial Distress & 1 \\
\hline & (1984) & $<0$ & Non Financial Distress & 0 \\
\hline \multirow[t]{2}{*}{4} & Grover & $<=-0.02$ & Financial Distress & 1 \\
\hline & (2001) & $>=0.01$ & Non Financial Distress & 0 \\
\hline \multirow[t]{3}{*}{5} & Khaira & 1 & Financial Distress & 1 \\
\hline & (2007) & $0.001-0.99$ & $\begin{array}{l}\text { Tingkatan kesulitan } \\
\text { keuangan }\end{array}$ & 0.001-0.999 \\
\hline & & 0 & Non Financial Distress & \\
\hline
\end{tabular}

From the Altman prediction model, numbers between 1.23 to 2.9 (grey area) are convert to intervals to produce values between 1 and 0 , for example for a score of 1,415 given a value of 0.1 ; a score of 1,601 was given a value of 0.2 ; and so on, resulting in a scale of 0 to 1 for each Altman score.

\section{Variable}

Variable used in this research is the score of the prediction model obtained from calculation result using formula of each model. Table 2 shows the calculation of financial distress score.

\section{Statistic analysis}

To determine the relationship between these predictive models, a correlation analysis of the scores generated from the Altman, Springate, Zmijewski, Grover, and Khaira models was applied. The correlation between scores of each model with 
the actual conditions was also implemented. The value of the correlation coefficient produced will indicate the strength of a relationship, whether strong, moderate, weak, or no correlation. Based on preliminary tests, scores of the Springate, Zmijewski, and Grover models only produce 0 and 1 whereas scores of Altman and Khaira produce a range between 0 to 1 .

These five models have the same concept, which is using financial ratios to predict financial distress. Thus, a correlation analysis is appropriate to understand the relationship between these concepts.

The detail steps of the analysis performed are as follows:

1. Calculate the score generated by each prediction model, namely the Altman, Springate, Zmijewski, Grover, and Khaira models.

2. Converting the resulting score on a scale of 0 to 1. Thus, it can be compared because it is equivalent. In this case, 1 is a company that is experiencing financial distress, 0 is a healthy company, whereas numbers between 0 and 1 indicate the degree of financial distress.

3. Conduct correlation analysis to determine the relationship between the scores of each model.

\section{RESULTS AND DISCUSSION}

\section{Descriptive Analysis}

Scores obtained from these prediction models and actual conditions one year before financial distress are presented in Table 3, whereas for two years before financial distress are presented in table 4. Score 1 indicates the financial distress condition, while score 0 indicates that there is no financial distress issue.

Based on the prediction results score of one year before the financial distress shows $24 \%$ of companies produce the same prediction score using the five models, namely GGRM, RDTX, LION, KOMI, GDYR, SMSM, TSPC, TCID, UNVR, AISA, POLY, ALKA, TPEN, and SOBI. All five models provide the same score to these companies.

In the two years before financial distress occurred, when the signs of distress were not yet clearly visible, $13.8 \%$ of the companies were predicted with the same score by the five models, namely STTP, GGRM, LION, GDYR, SMSM, AISA, ARGO, and MLIA.

The financial health scores of the companies using the five prediction models are presented in Table 5.

From 2015 to 2018, the number of companies observed has decreased from 58 companies to 46 companies. The reduction occurred because of delisting, no longer engaged in the manufacturing industry, or go private.

Out of the 46 companies, $10.1 \%$ have the same prediction results, namely DLTA, ULTJ, INCI, TSPC, and UNVR.

Table 3. Prediction Scores One Year Before Financial Distress and Actual Condition

\begin{tabular}{|c|c|c|c|c|c|c|c|}
\hline No & KODE & Altman & Springate & Zmijewski & Grover & Khaira & Aktual \\
\hline 1 & AQUA & 0.60 & 0 & 0 & 0 & 0.42 & 0 \\
\hline 2 & DLTA & 1 & 1 & 0 & 0 & 0.11 & 0 \\
\hline 3 & FAST & 0 & 0 & 0 & 0 & 0.04 & 0 \\
\hline 4 & INDF & 0.50 & 0 & 0 & 0 & 0.06 & 0 \\
\hline 5 & MLBI & 0.20 & 0 & 0 & 0 & 0.07 & 0 \\
\hline 6 & SHDA & 0.20 & 0 & 0 & 0 & 0 & 0 \\
\hline 7 & STTP & 0 & 0 & 1 & 0 & 0 & 0 \\
\hline 8 & ULTJ & 1 & 1 & 0 & 0 & 0.16 & 0 \\
\hline 9 & BATI & 0.10 & 1 & 1 & 0 & 0.91 & 0 \\
\hline 10 & GGRM & 0 & 0 & 0 & 0 & 0 & 0 \\
\hline 11 & RDTX & 0 & 0 & 0 & 0 & 0 & 0 \\
\hline 12 & INDR & 1 & 1 & 0 & 0 & 0.51 & 0 \\
\hline 13 & BATA & 0.55 & 0 & 0 & 0 & 0.16 & 0 \\
\hline 14 & LTLS & 0.7 & 0 & 0 & 0 & 0.01 & 0 \\
\hline 15 & DPNS & 0.45 & 0 & 0 & 0 & 0.01 & 0 \\
\hline 16 & EKAD & 0.75 & 0 & 0 & 0 & 0.02 & 0 \\
\hline 17 & $\mathrm{INCl}$ & 0 & 0 & 1 & 0 & 0.00 & 0 \\
\hline 18 & BRNA & 0.15 & 1 & 0 & 0 & 0.13 & 0 \\
\hline 19 & DYNA & 0.7 & 0 & 0 & 0 & 0 & 0 \\
\hline 20 & CTBN & 0.8 & 0 & 0 & 0 & 0 & 0 \\
\hline 21 & LION & 0 & 0 & 0 & 0 & 0 & 0 \\
\hline 22 & KOMI & 0 & 0 & 0 & 0 & 0 & 0 \\
\hline 23 & GDYR & 0 & 0 & 0 & 0 & 0 & 0 \\
\hline 24 & SMSM & 0 & 0 & 0 & 0 & 0 & 0 \\
\hline 25 & MERK & 0.60 & 0 & 0 & 0 & 0.17 & 0 \\
\hline 26 & TSPC & 0 & 0 & 0 & 0 & 0 & 0 \\
\hline 27 & TCID & 0 & 0 & 0 & 0 & 0 & 0 \\
\hline 28 & UNVR & 0 & 0 & 0 & 0 & 0 & 0 \\
\hline 29 & PSDN & 0.20 & 1 & 0 & 0 & 0.96 & 1 \\
\hline 30 & SKLT & 0.10 & 0 & 0 & 0 & 0.49 & 1 \\
\hline 31 & SMAR & 0.20 & 0 & 1 & 0 & 0.68 & 1 \\
\hline 32 & AISA & 1 & 1 & 1 & 1 & 1.00 & 1 \\
\hline 33 & ARGO & 1 & 1 & 1 & 0 & 0.96 & 1 \\
\hline 34 & TEJA & 0.10 & 1 & 1 & 0 & 0.97 & 1 \\
\hline 35 & GDWU & 1 & 1 & 1 & 0 & 1.00 & 1 \\
\hline 36 & BIMA & 0.80 & 0 & 1 & 0 & 0.55 & 1 \\
\hline 37 & SMCB & 1 & 1 & 1 & 0 & 0.99 & 1 \\
\hline 38 & SULI & 1 & 1 & 0 & 0 & 0.68 & 1 \\
\hline 39 & SUDI & 1 & 1 & 1 & 0 & 0.96 & 1 \\
\hline 40 & SAIP & 1 & 1 & 1 & 0 & 0.97 & 1 \\
\hline 41 & ETWA & 1 & 1 & 1 & 0 & 1.00 & 1 \\
\hline 42 & POLY & 1 & 1 & 1 & 1 & 1.00 & 1 \\
\hline 43 & AKPI & 1 & 1 & 1 & 0 & 0.96 & 1 \\
\hline 44 & ALKA & 1 & 1 & 1 & 1 & 1.00 & 1 \\
\hline 45 & JKSW & 1 & 1 & 0 & 0 & 0.97 & 1 \\
\hline 46 & IKAI & 1 & 1 & 0 & 0 & 0.95 & 1 \\
\hline 47 & KIAS & 1 & 1 & 1 & 0 & 0.98 & 1 \\
\hline 48 & MLIA & 1 & 1 & 0 & 0 & 0.97 & 1 \\
\hline 49 & KBLI & 1 & 1 & 1 & 0 & 1 & 1 \\
\hline 50 & VOKS & 1 & 1 & 1 & 0 & 1 & 1 \\
\hline 51 & ADMG & 1 & 1 & 1 & 0 & 1 & 1 \\
\hline 52 & IMAS & 0.10 & 1 & 1 & 0 & 1 & 1 \\
\hline 53 & INTD & 0.35 & 0 & 1 & 0 & 1 & 1 \\
\hline 54 & PICO & 1 & 1 & 0 & 0 & 0.23 & 1 \\
\hline 55 & TPEN & 1 & 1 & 1 & 1 & 1.00 & 1 \\
\hline 56 & SIPD & 0.2 & 0 & 0 & 0 & 0.09 & 1 \\
\hline 57 & SRSN & 1 & 1 & 1 & 0 & 0.99 & 1 \\
\hline 58 & SOBI & 1 & 1 & 1 & 0 & 1 & 1 \\
\hline
\end{tabular}

Source: Research data (processed) 
Tabel 4. Prediction Scores Two Years before Financial Distress and Actual Condition

\begin{tabular}{|c|c|c|c|c|c|c|c|}
\hline No & KODE & Altman & Springate & Zmijewski & Grover & Khaira & Aktual \\
\hline 1 & AQUA & 0.75 & 0 & 0 & 0 & 0.11 & 0 \\
\hline 2 & DLTA & 0.05 & 0 & 0 & 0 & 0.11 & 0 \\
\hline 3 & FAST & 0.45 & 1 & 0 & 0 & 0.01 & 0 \\
\hline 4 & INDF & 0.75 & 0 & 1 & 0 & 0.96 & 0 \\
\hline 5 & MLBI & 0.6 & 0 & 0 & 0 & 0 & 0 \\
\hline 6 & SHDA & 0.22 & 0 & 0 & 0 & 0 & 0 \\
\hline 7 & STTP & 0 & 0 & 0 & 0 & 0 & 0 \\
\hline 8 & ULTJ & 1 & 1 & 0 & 0 & 0.17 & 0 \\
\hline 9 & BATI & 0.09 & 0 & 1 & 0 & 0.77 & 0 \\
\hline 10 & GGRM & 0 & 0 & 0 & 0 & 0 & 0 \\
\hline 11 & RDTX & 0.65 & 0 & 0 & 0 & 0 & 0 \\
\hline 12 & INDR & 1 & 1 & 0 & 0 & 0.38 & 0 \\
\hline 13 & BATA & 0.4 & 0 & 0 & 0 & 0.48 & 0 \\
\hline 14 & LTLS & 0.71 & 0 & 0 & 0 & 0.01 & 0 \\
\hline 15 & DPNS & 0.6 & 0 & 0 & 0 & 0.01 & 0 \\
\hline 16 & EKAD & 0.56 & 0 & 0 & 0 & 0.05 & 0 \\
\hline 17 & INCI & 0.62 & 0 & 0 & 0 & 0.00 & 0 \\
\hline 18 & BRNA & 0.4 & 0 & 0 & 0 & 0.01 & 0 \\
\hline 19 & DYNA & 1 & 0 & 0 & 0 & 0.01 & 0 \\
\hline 20 & CTBN & 0.85 & 0 & 0 & 0 & 0 & 0 \\
\hline 21 & LION & 0 & 0 & 0 & 0 & 0 & 0 \\
\hline 22 & КомІ & 1 & 1 & 0 & 0 & 0.18 & 0 \\
\hline 23 & GDYR & 0 & 0 & 0 & 0 & 0 & 0 \\
\hline 24 & SMSM & 0 & 0 & 0 & 0 & 0 & 0 \\
\hline 25 & MERK & 0.82 & 0 & 0 & 0 & 0.01 & 0 \\
\hline 26 & TSPC & 0.45 & 0 & 0 & 0 & 0 & 0 \\
\hline 27 & TCID & 0.44 & 0 & 0 & 0 & 0.07 & 0 \\
\hline 28 & UNVR & 0 & 0 & 0 & 0 & 0.01 & 0 \\
\hline 29 & PSDN & 0 & 0 & 0 & 0 & 0.02 & 1 \\
\hline 30 & SKLT & 0.28 & 0 & 0 & 0 & 0.15 & 1 \\
\hline 31 & SMAR & 0.05 & 1 & 1 & 0 & 0.76 & 1 \\
\hline 32 & AISA & 1 & 1 & 1 & 1 & 1.00 & 1 \\
\hline 33 & ARGO & 1 & 1 & 1 & 1 & 1.00 & 1 \\
\hline 34 & TEJA & 1 & 1 & 1 & 0 & 0.98 & 1 \\
\hline 35 & GDWU & 0.05 & 0 & 0 & 0 & 0.45 & 1 \\
\hline 36 & BIMA & 0.3 & 1 & 1 & 0 & 1.00 & 1 \\
\hline 37 & SMCB & 1 & 1 & 0 & 0 & 0.42 & 1 \\
\hline 38 & SULI & 1 & 1 & 0 & 0 & 0.68 & 1 \\
\hline 39 & SUDI & 1 & 1 & 1 & 0 & 0.80 & 1 \\
\hline 40 & SAIP & 1 & 1 & 1 & 0 & 0.96 & 1 \\
\hline 41 & ETWA & 1 & 1 & 1 & 0 & 1.00 & 1 \\
\hline 42 & POLY & 1 & 1 & 0 & 0 & 0.80 & 1 \\
\hline 43 & AKPI & 1 & 1 & 1 & 0 & 1.00 & 1 \\
\hline 44 & ALKA & 0.02 & 1 & 0 & 0 & 0.65 & 1 \\
\hline 45 & JKSW & 0.24 & 0 & 0 & 0 & 0.59 & 1 \\
\hline 46 & IKAI & 1 & 1 & 0 & 0 & 0.55 & 1 \\
\hline 47 & KIAS & 1 & 0 & 0 & 0 & 0.46 & 1 \\
\hline 48 & MLIA & 1 & 1 & 1 & 1 & 1.00 & 1 \\
\hline 49 & KBLI & 1 & 1 & 1 & 0 & 1.00 & 1 \\
\hline 50 & VOKS & 0.3 & 0 & 0 & 0 & 0.35 & 1 \\
\hline 51 & ADMG & 1 & 1 & 1 & 0 & 0.88 & 1 \\
\hline 52 & IMAS & 0.35 & 0 & 0 & 0 & 0.67 & 1 \\
\hline 53 & INTD & 0.62 & 0 & 0 & 0 & 0.56 & 1 \\
\hline 54 & PICO & 1 & 1 & 0 & 0 & 0.23 & 1 \\
\hline 55 & TPEN & 1 & 1 & 1 & 0 & 0.93 & 1 \\
\hline 56 & SIPD & 0.13 & 0 & 0 & 0 & 0.20 & 1 \\
\hline 57 & SRSN & 1 & 1 & 0 & 0 & 0.88 & 1 \\
\hline 58 & SOBI & 1 & 0 & 0 & 0 & 0.39 & 1 \\
\hline
\end{tabular}

Correlation between the scores of Altman, Springate, Zmijewski, Grover, Khaira, and Actual

The correlation between the scores of five predicted model in one and two years prior to financial distress with the actual condition of the company at that time are presented in Table 6 .

Table 6 showed that the correlation coefficient is above 0.6 and significant data is the correlation between Altman - Springate $(0.681 * *)$ and Altman - Khaira $(0.603 * *)$ in the year prior to financial distress; Springate - Khaira $(0.796 * *)$ one year before financial distress occurred; and Zmijewski Khaira $(0.730 * *)$ one year and two years before financial distress. This correlation coefficient shows a strong correlation [18].
The Altman and Springate models have the same three financial ratios, namely working capital to total assets, earnings before interest and taxes to total assets, and sales to total assets. Altman and Khaira models do not have the same predictor, but likewise have a profitability ratio as well as include total liabilities items.

The Springate and Khaira models do not use the exact same financial ratios. The similarity is in the use of probability ratios, where Springate uses the ratio of earnings before interest and taxes to total assets while Khaira uses the ratio of net income to total assets. The Zmijewski model has three predictors and Khaira has two predictors. The two Khaira predictors are also Zmijewski's predictors.

The prediction model that did not correlate significantly at alpha 5\% was only the AltmanGrover model in the two years before the financial distress, even though the financial ratios used by the two were not much different.

Table 6 also shows the correlation between each model and the actual conditions when financial distress occurs. The highest correlation is the Khaira model one year and two years before financial distress $\left(0.873^{* *}\right.$ and $\left.0.708 * *\right)$, then the Springate model one year before financial distress $(0.672 * *)$, Zmijewski $(0.613 * *)$, and Altman one year before financial distress $(0.577 * *)$.

Overall, all predictions from all models correlate positively and significantly with actual conditions, except for Grover's model which is positively correlated but not significant in two years before financial distress. Grover's model has a weak correlation with the other four models. The Grover model is the only model among the five models that does not include debt as a predictor. Based on the correlation analysis, it can be seen that the right predictor for the condition of financial distress in Indonesia is profitability ratios and debt-related financial ratios.

The results of the five models financial health correlation applied to companies in Indonesia are presented in Table 7.

Table 7 shows that all the results of the correlation are positive. A strong and significant correlation at alpha $5 \%$ was found in the Altman Springate model in 2015 - 2018 (0.759**, 0.697 **, $0.561 * *$, and $0.680 * *$ ); Altman - Khaira in 2015 $2017\left(0.726^{* *}, 0.811^{* *}\right.$ and $\left.0.677^{* *}\right)$; Springate Khaira in $2015-2017\left(0.596 * *, 0.638^{* *}\right.$ and 0.567 $* *)$; and Zmijewski - Khaira in $2015-2017(0.823 * *$, $0.596^{* *}$ and $0.762^{* *}$ ). Weak correlations were found in the Grover model compared to the other four models. This finding reinforces the presumption that the prediction model that does not include the element of debt as a predictor is not properly applied to the condition of distress companies in Indonesia. 
Tabel 5. The Financial Health Scores year 2005, 2016, 2017 and 2018

\begin{tabular}{|c|c|c|c|c|c|c|c|c|c|c|c|c|c|c|c|c|c|c|c|c|c|}
\hline No & KODE & & 20 & 1 & 5 & & & 2 & 1 & 6 & & & 0 & 1 & 7 & & & 0 & 1 & 8 & \\
\hline & & A & $\mathrm{s}$ & $z$ & G & $\mathrm{K}$ & A & $\mathrm{s}$ & z & G & $\mathrm{K}$ & A & $\mathrm{s}$ & $\mathrm{z}$ & $G$ & $\mathrm{~K}$ & $\mathrm{~A}$ & $\mathrm{~s}$ & $z$ & G & $\mathrm{K}$ \\
\hline 1 & DLTA & 0 & 0 & 0 & 0 & 0 & 0 & 0 & 0 & 0 & 0 & 0 & 0 & 0 & 0 & 0 & 0 & 0 & 0 & 0 & 0 \\
\hline 2 & FAST & 0 & 0 & 0 & 0 & 0.08 & 0 & 0 & 0 & 0 & 0.04 & 0 & 0 & 0 & 0 & 0.08 & 0 & 0 & 0 & 0 & 0.08 \\
\hline 3 & INDF & 0.85 & 1 & 0 & 0 & 0.10 & 0.6 & 0 & 0 & 0 & 0.02 & 0.40 & 0 & 0 & 0 & 0.05 & 0.05 & 0 & 0 & 0 & 0.05 \\
\hline 4 & MLBI & 0.25 & 0 & 0 & 0 & 0.00 & 0 & 0 & 0 & 0 & 0.00 & 0 & 0 & 0 & 0 & 0.00 & 0 & 0 & 0 & 0 & 0 \\
\hline 5 & STTP & 0.25 & 0 & 0 & 0 & 0.01 & 0.4 & 0 & 0 & 0 & 0.02 & 0 & 0 & 0 & 0 & 0.01 & 0 & 0 & 0 & 0 & 0.01 \\
\hline 6 & ULTJ & 0 & 0 & 0 & 0 & 0 & 0 & 0 & 0 & 0 & 0 & 0 & 0 & 0 & 0 & 0 & 0 & 0 & 0 & 0 & 0 \\
\hline 7 & GGRM & 0.15 & 0 & 0 & 0 & 0.00 & 0 & 0 & 0 & 0 & 0.00 & 0 & 0 & 0 & 0 & 0.00 & 0 & 0 & 0 & 0 & 0 \\
\hline 8 & RDTX & 0 & 1 & 0 & 0 & 0.02 & 0 & 0 & 0 & 0 & 0.00 & 0 & 0 & 0 & 0 & 0.00 & 0 & 0 & 0 & 0 & 0 \\
\hline 9 & INDR & 0.95 & 1 & 0 & 0 & 0.53 & 0.95 & 1 & 0 & 0 & 0.61 & 0.25 & 0 & 0 & 0 & 0.64 & 0.72 & 0 & 0 & 0 & 0.64 \\
\hline 10 & BATA & 0 & 0 & 0 & 0 & 0 & 0 & 0 & 0 & 0 & 0.01 & 0 & 0 & 0 & 0 & 0 & 0 & 0 & 0 & 0 & 0 \\
\hline 11 & LTLS & 0.85 & 1 & 0 & 0 & 0.68 & 0.85 & 1 & 0 & 0 & 0.61 & 0.41 & 0 & 0 & 0 & 0.49 & 0.40 & 0 & 0 & 0 & 0 \\
\hline 12 & DPNS & 0 & 0 & 0 & 0 & 0 & 0 & 0 & 0 & 0 & 0 & 0 & 0 & 0 & 0 & 0.01 & 0 & 0 & 0 & 0 & 0.49 \\
\hline 13 & EKAD & 0 & 0 & 0 & 0 & 0 & 0 & 0 & 0 & 0 & 0 & 0 & 0 & 0 & 0 & 0 & 0 & 0 & 0 & 0 & 0.01 \\
\hline 14 & $\mathrm{INCl}$ & 0 & 0 & 0 & 0 & 0 & 0 & 0 & 0 & 0 & 0 & 0 & 0 & 0 & 0 & 0 & 0 & 0 & 0 & 0 & 0 \\
\hline 15 & BRNA & 1 & 1 & 0 & 0 & 0.44 & 0.95 & 1 & 0 & 0 & 0.28 & 1 & 1 & 0 & 0 & 0.95 & 1 & 1 & 0 & 0 & 0 \\
\hline 16 & CTBN & 0.80 & 1 & 0 & 0 & 0.06 & 0.40 & 1 & 0 & 0 & 0.06 & 0.35 & 1 & 0 & 0 & 0.39 & 0.35 & 1 & 0 & 0 & 0.95 \\
\hline 17 & LION & 0.15 & 0 & 0 & 0 & 0 & 0.25 & 0 & 0 & 0 & 0.01 & 0.65 & 0 & 0 & 0 & 0.06 & 0.75 & 0 & 0 & 0 & 0.39 \\
\hline 18 & GDYR & 0.55 & 1 & 0 & 0 & 0.32 & 0 & 1 & 0 & 0 & 0.19 & 0.71 & 1 & 0 & 0 & 0.54 & 0.55 & 0 & 0 & 0 & 0.06 \\
\hline 19 & SMSM & 0 & 0 & 0 & 0 & 0 & 0 & 0 & 0 & 0 & 0 & 0 & 0 & 0 & 0 & 0 & 0 & 0 & 0 & 0 & 0.54 \\
\hline 20 & MERK & 0 & 0 & 0 & 0 & 0 & 0 & 0 & 0 & 0 & 0 & 0 & 0 & 0 & 0 & 0 & 0.71 & 0 & 0 & 0 & 0 \\
\hline 21 & TSPC & 0 & 0 & 0 & 0 & 0 & 0 & 0 & 0 & 0 & 0 & 0 & 0 & 0 & 0 & 0 & 0 & 0 & 0 & 0 & 0 \\
\hline 22 & TCID & 0 & 0 & 0 & 0 & 0 & 0 & 0 & 0 & 0 & 0 & 0 & 0 & 0 & 0 & 0 & 0 & 0 & 0 & 0 & 0.01 \\
\hline 23 & UNVR & 0 & 0 & 0 & 0 & 0 & 0 & 0 & 0 & 0 & 0 & 0 & 0 & 0 & 0 & 0 & 0 & 0 & 0 & 0 & 0 \\
\hline 24 & PSDN & 0.95 & 1 & 1 & 0 & 1.00 & 0.90 & 1 & 0 & 1 & 0.62 & 0.87 & 0 & 0 & 0 & 0.17 & 0.60 & 0 & 0 & 0 & 0 \\
\hline 25 & SKLT & 0.20 & 0 & 0 & 0 & 0.11 & 0.45 & 0 & 0 & 0 & 0.09 & 0.61 & 0 & 0 & 0 & 0.15 & 0.70 & 0 & 0 & 0 & 0.17 \\
\hline 26 & SMAR & 0.60 & 1 & 0 & 0 & 0.79 & 0.6 & 0 & 0 & 0 & 0.19 & 0.43 & 1 & 0 & 0 & 0.21 & 0.55 & 0 & 0 & 0 & 0.15 \\
\hline 27 & AISA & 0.90 & 1 & 0 & 0 & 0.13 & 0.78 & 0 & 0 & 0 & 0.03 & 1 & 1 & 1 & 0 & 1.00 & 1 & 1 & 1 & 0 & 0.21 \\
\hline 28 & ARGO & 1 & 1 & 1 & 1 & 1.00 & 1 & 1 & 1 & 1 & 1.00 & 0 & 0 & 1 & 0 & 1.00 & 0 & 0 & 1 & 0 & 1 \\
\hline 29 & BIMA & 1 & 0 & 1 & 0 & 1.00 & 1 & 0 & 1 & 0 & 0.98 & 1 & 1 & 0 & 0 & 0.86 & 1 & 1 & 0 & 0 & 1 \\
\hline 30 & SMCB & 1 & 1 & 0 & 0 & 0.23 & 1 & 1 & 0 & 1 & 0.61 & 1 & 1 & 1 & 0 & 0.97 & 1 & 1 & 1 & 0 & 0.86 \\
\hline 31 & SULI & 1 & 1 & 1 & 0 & 1 & 1 & 1 & 1 & 0 & 1 & 1 & 1 & 1 & 1 & 1 & 1 & 1 & 1 & 1 & 0.97 \\
\hline 32 & POLY & 1 & 1 & 1 & 1 & 1 & 1 & 1 & 1 & 1 & 1 & 1 & 0 & 1 & 0 & 1 & 1 & 0 & 1 & 0 & 1.0 \\
\hline 33 & AKPI & 1 & 1 & 0 & 0 & 0.46 & 1 & 1 & 0 & 1 & 1 & 0.15 & 1 & 0 & 0 & 0.50 & 0.15 & 0 & 0 & 0 & 1 \\
\hline 34 & ALKA & 0 & 0 & 0 & 0 & 0.47 & 0.95 & 1 & 0 & 0 & 0.28 & 0 & 0 & 0 & 0 & 0.50 & 0 & 0 & 1 & 0 & 0.50 \\
\hline 35 & JKSW & 1 & 1 & 1 & 0 & 1 & 0 & 0 & 1 & 0 & 0.44 & 1 & 0 & 1 & 0 & 1.00 & 1 & 1 & 1 & 0 & 0.50 \\
\hline 36 & IKAI & 1 & 1 & 1 & 1 & 1 & 0.95 & 0 & 1 & 0 & 1.00 & 1 & 1 & 1 & 1 & 1.00 & 1 & 1 & 0 & 1 & 1 \\
\hline 37 & KIAS & 0.25 & 1 & 0 & 0 & 0.29 & 1 & 1 & 0 & 1 & 1.00 & 0.55 & 1 & 0 & 0 & 0.11 & 0.50 & 1 & 0 & 0 & 1 \\
\hline 38 & MLIA & 0.95 & 1 & 1 & 0 & 0.97 & 0 & 1 & 1 & 0 & 0.11 & 0.15 & 0 & 0 & 0 & 0.63 & 0.11 & 0 & 0 & 0 & 0.11 \\
\hline 39 & KBLI & 0.25 & 0 & 1 & 0 & 1.00 & 1 & 1 & 1 & 0 & 0.89 & 0.85 & 0 & 0 & 0 & 0.00 & 0 & 0 & 0 & 0 & 0.63 \\
\hline 40 & VOKS & 0.95 & 1 & 0 & 0 & 0.70 & 0 & 0 & 0 & 0 & 0.00 & 0.6 & 0 & 0 & 0 & 0.10 & 0.51 & 0 & 0 & 0 & 0.00 \\
\hline 41 & ADMG & 0 & 1 & 0 & 0 & 0.55 & 0.5 & 0 & 0 & 0 & 0.02 & 0.35 & 1 & 0 & 0 & 0.22 & 0 & 0 & 0 & 0 & 0.10 \\
\hline 42 & IMAS & 1 & 1 & 0 & 0 & 0.78 & 1 & 1 & 0 & 0 & 0.58 & 1 & 1 & 0 & 0 & 0.79 & 1 & 1 & 0 & 0 & 0.22 \\
\hline 43 & INTD & 0 & 0 & 0 & 0 & 0.01 & 1 & 1 & 0 & 0 & 0.87 & 0.69 & 0 & 0 & 0 & 0.02 & 0 & 0 & 0 & 0 & 0.79 \\
\hline 44 & PICO & 0.6 & 0 & 0 & 0 & 0.32 & 0 & 0 & 0 & 0 & 0.01 & 0.49 & 0 & 0 & 0 & 0.40 & 0.30 & 0 & 0 & 0 & 0.02 \\
\hline 45 & SIPD & 1 & 1 & 1 & 1 & 1 & 0.95 & 1 & 0 & 0 & 0.43 & 1 & 1 & 1 & 0 & 1.00 & 0.35 & 0 & 0 & 0 & 0.40 \\
\hline 46 & SRSN & 0.6 & 0 & 0 & 0 & 0.06 & 0.90 & 1 & 0 & 0 & 0.21 & 0.45 & 0 & 0 & 0 & 0.05 & 0.71 & 0 & 0 & 0 & 1 \\
\hline
\end{tabular}

Source: Research data (processed)

A = Altman model; $\mathrm{S}=$ Springate model; $\mathrm{Z}=$ Zmijewski model $; \mathrm{G}=$ Grover model; $\mathrm{K}=$ Khaira model

Tabel 6. Correlation between the scores of Altman, Springate, Zmijewski, Grover, Khaira, and Actual.

\begin{tabular}{|c|c|c|c|c|c|c|}
\hline Year & & Springate & Zmijewski & Grover & Khaira & Aktual \\
\hline One Year Before & Altman & $\begin{array}{l}0.681^{* *} \\
(0.000)\end{array}$ & $\begin{array}{l}0.350^{* *} \\
(0.007)\end{array}$ & $\begin{array}{l}0.272^{* *} \\
(0.000)\end{array}$ & $\begin{array}{l}0.603^{* *} \\
(000)\end{array}$ & $\begin{array}{l}0.577^{\star * *} \\
(0.000)\end{array}$ \\
\hline Two Year Before & & $\begin{array}{l}0.577^{* *} \\
(0.000)\end{array}$ & $\begin{array}{l}0.323^{*} \\
(0.014)\end{array}$ & $\begin{array}{l}0.239 \\
(0.70)\end{array}$ & $\begin{array}{l}0.446^{* *} \\
(0.000)\end{array}$ & $\begin{array}{l}0.285^{*} \\
(0.035)\end{array}$ \\
\hline One Year Before & Springate & & $\begin{array}{l}0.493^{* * *} \\
(0.000)\end{array}$ & $\begin{array}{l}0.263^{*} \\
(0.046)\end{array}$ & $\begin{array}{l}0.796^{* *} \\
(0.000)\end{array}$ & $\begin{array}{l}0.672^{* * *} \\
(0.000)\end{array}$ \\
\hline Two Years Before & & & $\begin{array}{l}0.543^{* * *} \\
(0.000)\end{array}$ & $\begin{array}{l}0.278^{*} \\
(0.035)\end{array}$ & $\begin{array}{l}0.673^{* * *} \\
(0.000)\end{array}$ & $\begin{array}{l}0.552^{* * *} \\
(0.000)\end{array}$ \\
\hline One Year Before & Zmijewski & & & $\begin{array}{l}0.313^{*} \\
(0.017)\end{array}$ & $\begin{array}{l}0.730 * * \\
(0.000)\end{array}$ & $\begin{array}{l}0.613^{* * *} \\
(0.000)\end{array}$ \\
\hline Two Years Before & & & & $\begin{array}{l}0.395^{* * *} \\
(0.002)\end{array}$ & $\begin{array}{l}0.803^{* * *} \\
(0.000)\end{array}$ & $\begin{array}{l}0.395^{* * *} \\
(0.003)\end{array}$ \\
\hline One Year Before & Grover & & & & $\begin{array}{l}0.303^{*} \\
(0.021)\end{array}$ & $\begin{array}{l}0.256 \\
(0.060)\end{array}$ \\
\hline Two Years Before & & & & & $\begin{array}{l}0.356^{* *} \\
(0.006)\end{array}$ & $\begin{array}{l}0.219 \\
(0.108)\end{array}$ \\
\hline One Year Before & & & & & & $\begin{array}{l}0.873^{* *} \\
(0.000)\end{array}$ \\
\hline Two Years Before & & & & & & $\begin{array}{l}0.708^{* * *} \\
(0.000)\end{array}$ \\
\hline
\end{tabular}

Source: Research data (processed)

$\mathrm{N}=58$

** Correlation is significant at the 0.01 level

*Correlation is significant at the 0.05 level 
Tabel 7. The correlation of Financial Health Scores using Altman, Springate, Zmijewski, Grover, and Khaira Prediction Models

\begin{tabular}{|c|c|c|c|c|c|}
\hline & Year & Springate & Zmijewski & Grover & Khaira \\
\hline \multirow[t]{8}{*}{ Altman } & 2015 & $0.759^{* * *}$ & $0.529^{* * *}$ & $0.370^{*}$ & $0.726^{* *}$ \\
\hline & & $(0.000)$ & $(0.000)$ & $(0.011)$ & $(0.000)$ \\
\hline & 2016 & $0.697^{* *}$ & 0.288 & $0.452^{* *}$ & $0.811^{* *}$ \\
\hline & & $(0.000)$ & $(0.052)$ & $(0.002)$ & $(0.000)$ \\
\hline & 2017 & $0.561^{* *}$ & $0.529^{* *}$ & $0.312^{*}$ & $0.677^{* *}$ \\
\hline & & $(0.000)$ & $(0.000)$ & $(0.035)$ & $(0.000)$ \\
\hline & 2018 & $0.680^{* *}$ & $0.362^{*}$ & $0.336^{*}$ & $0.370^{*}$ \\
\hline & & $(0.000)$ & $(0.015)$ & $(0.024)$ & $(0.012)$ \\
\hline \multirow[t]{8}{*}{ Springate } & 2015 & & $0.316^{*}$ & $0.309^{*}$ & $0.596^{* *}$ \\
\hline & & & $(0.032)$ & $(0.037)$ & $(0.000)$ \\
\hline & 2016 & & 0.198 & $0.462^{* *}$ & $0.638^{* *}$ \\
\hline & & & $(0.188)$ & $(0.001)$ & $(0.000)$ \\
\hline & 2017 & & $0.320^{*}$ & $0.322^{*}$ & $0.567^{* *}$ \\
\hline & & & $(0.030$ & (0.029) & $(0.000)$ \\
\hline & 2018 & & $0.361^{*}$ & $0.403^{* *}$ & $0.432^{* *}$ \\
\hline & & & $(0.015)$ & $(0.006)$ & $(0.003)$ \\
\hline \multirow[t]{8}{*}{ Zmijewski } & 2015 & & & $0.586^{* *}$ & $0.823^{* * *}$ \\
\hline & & & & $(0.000)$ & $(0.000)$ \\
\hline & 2016 & & & 0.163 & $0.596^{* *}$ \\
\hline & & & & (0.279) & $(0.000)$ \\
\hline & 2017 & & & $0.465^{* *}$ & $0.762^{* *}$ \\
\hline & & & & $(0.001)$ & $(0.000)$ \\
\hline & 2018 & & & 0.205 & $0.401^{* *}$ \\
\hline & & & & $(0.177)$ & $(0.006)$ \\
\hline \multirow[t]{8}{*}{ Grover } & 2015 & & & & $0.484^{* *}$ \\
\hline & & & & & $(0.001)$ \\
\hline & 2016 & & & & $0.575^{* *}$ \\
\hline & & & & & $(0.000)$ \\
\hline & 2017 & & & & $0.357^{*}$ \\
\hline & & & & & $(0.015)$ \\
\hline & 2018 & & & & $0.347^{*}$ \\
\hline & & & & & (0.019) \\
\hline
\end{tabular}

Source: Research data (processed)

$\mathrm{n}=46$

${ }^{*}$ Correlation is significant at the 0.01 level

${ }^{* *}$ Correlation is significant at the 0.05 level

Prediction models with equalized scores are expected to have a positive correlation, which means if a model predicts financial distress in one company, then the other models will predict that too. But on alpha 5\% empirical data shows that:

1. The first hypothesis is supported by empirical data. The financial distress prediction model of Altman, Springate, Zmijewski, Grover, and Khaira one year before the occurrence of financial distress is significant and showed the same trend.

2. The second hypothesis is supported by empirical data. The financial distress prediction models of Altman, Springate, Zmijewski, Grover, and Khaira in the two years before the financial distress is significant and showed the same trend, however the correlation between Altman and Grover were not significant.

3. The third hypothesis is supported by empirical data. The financial distress prediction model of Altman, Springate, Zmijewski, Grover and
Khaira one year before financial distress with the actual conditions of the company showed the same trend, on the other hand the correlation score from the Grover model was not significant.

4. The fourth hypothesis is supported by empirical data. The financial distress prediction model of Altman, Springate, Zmijewski, Grover and Khaira in the two years before financial distress with the actual conditions of the company showed the same trend, however only the correlation score of Grover model was not significant.

5. The fifth hypothesis is supported by empirical data. Correlation scores of financial health prediction models among Altman, Springate, Zmijewski, Grover, and Khaira in 2015, 2016, 2017 and 2018 shows the same trend, on the other hand the correlation score between Altman-Zmijewski in 2016, Springate-Zmijewski in 2016, Grover - Zmijewski in 2016 and 2018 were not significant. 
The strong correlation in some models may be caused by the causes of almost the same distress so that the resulting cut off point becomes appropriate. Apart from that the predictors used are also appropriate.

When compared with the theory of financial distress which states that financial distress are influenced by elements of the balance sheet influence and earnings effect [19], then for the condition of manufacturing companies in Indonesia, financial distress are more influenced by financial leverage and profitability.

When associated with the types of theoretical models that determine the causes of bankruptcy, namely balance sheet decomposition measures, gambler's ruin theory, cash management theory, and credit risk theories, then by looking at predictors of research results it can be concluded that the suitable theoretical model is the balance sheet decomposition measures.

Common ratio categories used to predict financial distress are debt-repaying ability, earnings ability, financial structure and management efficiency [5]. This finding found that more suitable ratios to predict financial distress in Indonesia are earning ability and financial structure. It is because when the portion of debt in the capital structure increases, especially debt in foreign currency [4], the possibility of bankruptcy also increases. Foreign exchange rates put pressure on companies in Indonesia, especially debt in foreign currencies [7]. Capital structure is also related to economic conditions. If the economy is bad, interest rates increase, consequently the amount of debt increases [9].

In this study, earning ability or profitability uses the ratio of net income to total assets (ROA). ROA is also a proxy of company performance [26]. The company's performance means the company's work performance [8]. The result of this study indicates that the company's performance largely determines the financial health status of the company, the better the company's performance the healthier the company.

The financial distress prediction in Indonesia is closer to the model produced by Altman, Springate, Khaira, and Zmijewski. The Grover model is not suitable to use in conditions of financial distress in Indonesia because it does not have a predictor of leverage. Furthermore, this financial distress prediction model can also be used to predict the financial health of a company.

\section{CONCLUSION}

The most accurate model to predict the conditions of financial distress in Indonesia is the Khaira model, and the most inaccurate model is the.
It probably caused by the lack of a predictor in the form of leverage ratio in Grover model, because this model only uses liquidity and profitability ratios. In Indonesia, most companies that experience financial distress have problems with their debts so that if the leverage ratio is not included as a predictor then the predictive power will be weak.

Prediction models that have strong correlations are Zmijewski-Khaira, Springate-Khaira, Altman-Springate, and Altman-Khaira. These models have elements of profitability and leverage. This present research contributes on providing a most accurate model to predict the financial distress condition in Indonesia. The model benefits for decision makers and business consultants.

\section{Limitation and Suggestion}

The use of a financial distress prediction model must consider the cause of the financial distress properly. If that is caused by financial and operational problems then the proper forecast (the right element or factor) is the ratio between the profitability and financial leverage. If the cause of the financial distress is due to less experience or wrong strategy of operation then the correct element or factor that must be properly or suitably chosen is the ratio between efficiency and liquidity. As a rule of thumb or general knowledge is that there is no single model that can be utilized for all situations.

To confidently predict the financial distress in Indonesia which is mostly due to the huge amount of debt and negative net income, a good prediction model is a model that accommodates the ratio of profitability and leverage. Furthermore, in using the financial distress prediction model to measure the financial health, the observation of fit levels in terms of leverage, profitability, liquidity, or asset management must be thoroughly explained. In principle, all the mentioned factors depend on a forecast approach used in a prediction model.

This present study only focuses on a correlation among five prediction models. A further research will include other prediction models such as the Fulmer and CA-Score models.

\section{REFERENCES}

[1] Adinata, G. (2019). CSR Expenditures, Financial Distress Prediction, and Reputation: A Pathway Analysis. Perspektif Akuntansi, 2(1), 1-18.

[2] Altman, E.I., Haldeman, R.G, and Narayanan, P. (1977). Zeta ${ }^{\text {TM }}$ Analysis - A New Model to Identify Bankruptcy Risk Corporations. Journal of Banking and Finance, 1, 29-54.

[3] Andrade, G., and Kaplan, S. (1998). How Costly is Financial (Not Economic) Distress? 
Evidence from Highly Leveraged Transactions that Became Distressed. The Journal of Finance, 53(5), 1443-1493.

[4] Arasu, R., Balaji, C.D., Kumar, S.P., and Thamizhselvi, N. (2013). Applicability of Fulmer and Springate Models for Predicting Financial Distress of Firms in the Finance Sector - An Empirical Analysis. Journal of Finance and Risk Management, 4(1), 1-9.

[5] Bal, J., Cheung, Y., and Wu, H.C. (2013). Entropy for Business Failure Prediction: An Improved Prediction Model for the Construction Industry. Advances in Decision Sciences, 114.

[6] Ben, D. A., R, A. M. D., and Topowijono. (2015). Analisis Metode Springate (S-Score) sebagai Alat untuk Memprediksi Kebangkrutan Perusahaan (Studi pada Perusahaan Property dan Real estate yang Listing di Bursa Efek Indonesia pada Tahun 2011 - 2013). Jurnal Administrasi Bisnis, 21(1), 1-9.

[7] Christiawan, Y. J., and Rahmiati, A., (2014). Earning Management of Firms Reporting Long Term Debt: an Alternative Method. Jurnal Akuntansi Keuangan, 16(2), 113-120.

[8] Fachrudin, K.A. (2011). Analisis Pengaruh Struktur Modal, Ukuran Perusahaan, dan Agency Cost terhadap Kinerja Perusahaan. Jurnal Akuntansi Keuangan, 13(1), 47-46.

[9] Fachrudin, K.A., Kesulitan Keuangan Perusahaan dan Personal, USU Press., 2008.

[10] Grice, J.S., and Ingram, R.W. (2001). Test of the generalizability of Altman's bankruptcy prediction model. Journal of Business Research, 54, 53-61.

[11] Grover, J.S., Validation of Cash Flow Model: a New Bankruptcy Approach, Dissertation, Nova Southeastern University., 2001.

[12] Gusni, W., Sri, S.P., and Silvana. (2019). Predicting Financial Distress : a Case Study of Indonesia Coal Firms. Global Business and Management Research, 11(1), 186-194.

[13] Halteh, K., Kumar, K., and Gepp, A. (2018). Financial distress prediction of Islamic Banks using tree-based stochastic techniques. Managerial Finance, 44(6), 759-773.

[14] Huo, Y. H. (2006). Bankruptcy Sitiation Model in Small Business: the Case of Restaurant Firms. Hospitality Review, 2(24), 49-58.

[15] Juniarti. (2013). Good Corporate Governance and Predicting Financial Distress using Logistic and Probit Regression Model. Jurnal Akuntansi Keuangan, 15(1), 43-50.
[16] Kasilingam, R and Ramasundaram, G. (2012). Predicting Solvency of Non-Banking Financial Institutions in India Using Fulmer and Springate Model. Journal of Services Research, $12(1), 65-88$.

[17] Kumari, N. (2013). Evaluation of Financial Health of MMTC of India: A Z Score Model. European Journal of Accounting and Finance Research, 1(1), 36-43.

[18] Lind, D.A, Marchal, W. G., and Wathen, S. A., Statistical Techniques in Business and Economics, 17th Edition, McGraw-Hill Irwin., 2019.

[19] Nketiah, E. T. Analyzing Investment Decisions Using Altman's Model to Predict Organizational Financial Distress, Dissertation, Capella University., United States of America, 2017.

[20] Norita. (2016). An Analysis of Telecommunication Vendor Company Bankruptcy Potency Based on the Problematic Financial Ratio with Altman, SpringateAnd Zmijewski Methods. The International Journal of Organizational Innovation, 8(4), 234-250.

[21] Parvin, Afroza, Benazir Rahman, dan Alrafa Akter Nitu. (2013). Prediction of Financial Health of Banking Industry in Bangladesh Using Altman's Z Score: A Comparison Between State-Owned Commercial Banks and Private Commercial Banks. Proceeding of the International Conference for Bankers and Academics, 335-344.

[22] Ross, S. A., Westerfield, R. W., and Jaffe, J., Corporate Finance, Tenth edition, McGraw Hill Irwin., 2013.

[23] Shahwan, T. M. (2015). The Effects of Corporate Governance on Financial Performance and Financial Distress: Evidence from Egypt. Corporate Governance, 15(5), 641-662.

[24] Sinarti and Sembiring, T.M. (2015). Bankruptcy Prediction Analysis of Manufacturing Companies Listed in Indonesia Stock Exchange. International Journal of Economics and $\mathrm{Fi}$ nancial Issues, 5, 354-359.

[25] Springate, G. L. (1978). Predicting the Possibility of Failure in a Canadian Firms. Research Project, January, Simon Fraser University, Canada.

[26] Wiranata, Y. A. and Nugrahanti, Y. W. (2013). Pengaruh Struktur Kepemilikan terhadap Profitabilitas Perusahaan Manufaktur di Indonesia. Jurnal Akuntansi Keuangan, 15(1), 1526.

[27] Zmijewski, M. E., Essay on Corporate Bankruptcy, Dissertation, University of New York., 1984. 